\title{
Vertebrate herbivores and ecosystem control: cascading effects of faeces on tundra ecosystems
}

\author{
René van der Wal, Richard D. Bardgett, Kathryn A. Harrison and Audun Stien
}

\begin{abstract}
Van der Wal, R., Bardgett, R. D., Harrison, R. D. and Stien, A. 2004. Vertebrate herbivores and ecosystem control: cascading effects of faeces on tundra ecosystem. - Ecography 27: 242-252.
\end{abstract}

\begin{abstract}
We tested the hypothesis that large herbivores manipulate their own food supply by modifying soil nutrient availability. This was investigated experimentally by determining the impact of faeces on grasses, mosses and soil biological properties in tundra ecosystems. For this, we increased the density of reindeer Rangifer tarandus platyrhynchus faeces and studied the response of a tundra system on Spitsbergen to this single faecal addition treatment for four subsequent years. From the third year onwards faecal addition had unambiguously enhanced the standing crop of grasses, as evidenced by an increase in both shoot density and mass per shoot. Although reindeer grazing across experimental plots was positively related to the abundance of grasses in anyone year, the increase in grass abundance in fouled plots failed to result in greater grazing pressure in those plots. Faecal addition enhanced soil microbial biomass $\mathrm{C}$ and N, particularly under wet conditions where faecal decay rates were greatest, whilst grasses appeared to benefit from faeces under dry conditions. Whilst growth of grasses and soil microbial biomass were stimulated by faecal addition, the depth of the extensive moss layer that is typical of tundra ecosystems was significantly reduced in fouled plots four years after faecal addition. The greatest reduction in moss depth occurred where fouling increased soil microbial biomass most, suggesting that enhanced decomposition of moss by a more abundant microbial community may have caused the reduced moss layer depth in fouled plots. Our field experiment demonstrates that by the production of faeces alone, vertebrate herbivores greatly impact on both above- and belowground components of tundra ecosystems and in doing so manipulate their own food supply. Our findings verify the assertion that grazing is of fundamental importance to tundra ecosystem productivity, and support the hypothesis that herbivory is instrumental in promoting grasses whilst suppressing mosses. The widely observed inverse relationship between grass and moss abundance in the field may therefore reflect the long history of plant-herbivore interactions in tundra ecosystems.
\end{abstract}

R.vanderWal(rvdw@ceh.ac.uk) Centre for Ecology and Hydrology, Hill of Brathens, Banchory, Scotland AB31 4BY. - R. D. Bargett and K. A. Harrison, Inst of Environmental and Natural Scienciences, Univ. Lancaster, Lancaster, U.K. LA14YQ - A. Stien, Centre for Ecology and Hydrology, The Univ. Centre in Svalbard (UNIS), N-9171 Longyearbyen, Norway.

Large herbivores are widely recognised as important drivers of vegetation change, strongly influencing both the structure and diversity of plant communities (Augustine and McNaughton 1998, Olff and Ritchie 1998). Herbivores can directly affect plant communities either by suppressing grazing-sensitive species or by influen- cing the competitive balance between plant species, providing those which are least sensitive to grazing damage with an advantage (Louda et al. 1990, Pacala and Crawley 1992). There is an increasing recognition of the importance of indirect effects of herbivores on plant community attributes. A wide variety of such indirect

Accepted 30 September 2003

Copyright (C) ECOGRAPHY 2004

ISSN 0906-7590 
herbivore effects have been identified, but central to most is the alteration of the quantity and quality of organic matter that is returned to the soil, hence influencing soil nutrient cycling (Hobbs 1996, Bardgett et al. 1998a, Wardle 2002, Bardgett and Wardle 2003). For instance, selective grazing can promote the dominance of plants that are better defended against herbivores and produce poor quality litter, thereby reducing rates of decomposition and nutrient mineralisation (Pastor et al. 1988). In many grazing systems, however, palatable plant species that are able to tolerate grazing have gained dominance instead, resulting in the production of high quality litter and enhanced nutrient cycling (Wedin and Tilman 1990, Grime et al. 1996).

Another way in which herbivores influence soil processes is by the return of animal-excreta that shortcuts the litter decomposition pathway, providing highly decomposable resources that are rich in labile nutrients. Faeces and urine can stimulate soil microbial biomass and activity (Frank and Evans 1997, Bardgett et al. 1998a), net $\mathrm{C}$ and $\mathrm{N}$ mineralisation (Molvar et al. 1993), and ultimately plant $\mathrm{N}$ acquisition and growth (Hamilton and Frank 2001). Of all grazing effects, this latter process is commonly promoted as one of the key mechanisms by which grazers stimulate plant growth in grassland (McNaughton et al. 1997, Frank and Groffman 1998), allowing herbivores to manipulate their own food supply (Hik and Jefferies 1990, Drent and Van der Wal 1999).

The ability of herbivores to increase the turnover rates of nutrients, thereby sustaining the production of preferred forage plants, may be of particular importance in strongly resource-limited environments, such as arctic tundra ecosystems where herbivore food supplies are low (Jefferies 1988). However, it has been suggested that rapid recycling of nutrients through herbivores may not result in an increase in plant biomass in arctic and boreal systems due to the relatively large proportions of reserves below-ground (Jefferies et al. 1994, Wegener and Odasz-Albrigtsen 1998). Such stores buffer the plant to the numerous stochastic events that are characteristic to tundra ecosystems, and hence may minimise any longterm effects of herbivores on them.

There is a growing body of evidence, however, indicating that tundra ecosystems are strongly influenced by grazing animals (Manseau et al. 1996, Jano et al. 1998, Virtanen 2000, Olofsson et al. 2001, Van der Wal et al. 2001a, b, Stark and Grellmann 2002). These cold systems, which are often dominated by mosses and lichens, were found to be particularly prone to indirect herbivore effects. For instance, grazing and trampling were instrumental in reducing the depth of the moss layer, which raised soil temperature from which grasses in particular benefited (Van der Wal et al. 2001a, 2004, Brooker and Van der Wal 2003). Developing a mechanistic understanding of herbivore impacts on tundra ecosystems has become of increasing importance since grazing pressure in many regions of the Arctic has intensified (Olofsson et al. 2001, Forchhammer et al 2002, Jefferies and Rockwell 2002).

Here we provide experimental evidence on the indirect effects of large herbivores on tundra ecosystems. Specifically, we test the hypothesis that large herbivores manipulate their own food supply by modifying soil nutrient availability through investigating experimentally the impact of reindeer Rangifer tarandus platyrhynchus faeces on the performance of grasses, mosses and soil biological properties in a tundra ecosystem in high-arctic Spitsbergen.

\section{Materials and methods}

\section{Site description}

The study was carried out in Semmeldalen, Nordenskiöldland, Spitsbergen $\left(15^{\circ} 20^{\prime} \mathrm{E}, 77^{\circ} 90^{\prime} \mathrm{N}\right)$. This higharctic inland valley is the central part of the ColesdalenReindalen valley system. Semmeldalen extends over 8 $\mathrm{km}$ and has a resident population of 90-330 wild reindeer, reaching a density that is among the highest for the Svalbard archipelago (Øritsland and Alendal 1986, Van der Wal and Brooker 2004). Hunting pressure on Svalbard reindeer is generally very low, and not permitted in our study area. There are no large predators and unlike the situation in Fennoscandia, there is no reindeer husbandry. The snow-free plant growing season is typically less than three months (early June-late August). Over this period, average air temperature and precipitation are low, typically $4.5^{\circ} \mathrm{C}$ and $45 \mathrm{~mm}$, respectively. These cool, dry conditions combined with the limited soil nutrient availability in the skeletal soils means that vegetation cover is largely restricted to shallow slopes and valley bottoms where snow melt water is abundant. Semmeldalen is composed of a diverse array of plant communities, ranging from very dry ridge communities with Salix polaris and Dryas octopetala to wet marshes dominated by Dupontia spp. and Eriophorum scheuchzeri. Peak standing crops of vascular plants are typically $20-65 \mathrm{~g} \mathrm{~m}^{-2}$ (Van der Wal unpubl.); an order of magnitude less than found in temperate grazing systems. Due to persistent reindeer grazing pressure lichen cover is minimal (Van der Wal et al. 2001b) but moss cover is extensive in most plant communities.

Reindeer utilise habitats sequentially over the growing season, predominantly grazing the dry ridge and sedgewillow heaths early in the growing season and progressively feeding on moist grass-rich tundra through the summer. Our study focuses on the latter habitat which is commonly found as patches on gentle slopes throughout the valley system, with a relatively high density of grasses Poa alpigena, P. arctica, Festuca cryophila, and Alope- 
curus borealis and a relatively shallow moss layer dominated by Tomentypnum nitens, Sanionia uncinata, Aulacomnium spp. and Polytrichum spp. Although almost the whole valley system is used by reindeer, grassrich communities are selected for by reindeer during large part of the growing season. During the summers of 1997 and 1998 a third of all reindeer were observed feeding on this grass-rich community. Reindeer faeces is present in all vegetation types across the whole study system, yet at widely different densities. Standing crop of faeces on the grass-rich focal communities was found to approach the average for the study system as a whole (Van der Wal et al. 2000a).

\section{Experimental design}

We employed a typical randomised block design to determine the effects of faeces on areas of grass-rich tundra. On 1 September 1997 we added faeces to 14 plots $(5 \times 5 \mathrm{~m})$ whilst leaving 14 similar-sized nearby control plots untreated. The blocks (sets of one control and one fouled plot) were spaced $>20 \mathrm{~m}$ apart. We used a randomisation procedure to determine which plots (within a block) would receive additional faeces. Each treated plot was supplemented with $10.6 \mathrm{~kg}$ of fresh reindeer faeces, uniformly spread out as small pats, creating a relatively high dropping density equivalent to 5.6 pats $\mathrm{m}^{-2}$. Natural summer pat density, accumulated between July 1998 and August 1999, was recorded in previously cleared $4 \mathrm{~m}^{2}$ plots positioned in a wide range of habitats, and ranged from 0 to 2.5 summer pats $\mathrm{m}^{-2}$. For those plots utilised by reindeer, average density was 0.64 summer pats $\mathrm{m}^{-2}(\mathrm{SD}=0.45, \mathrm{~N}=43)$. Although the natural range of reindeer pats deposited in a single year was found to be lower than the artificially created densities in fouled plots, densities may be realistic when considering the accumulation of faeces over several years in preferred habitats, as faecal decomposition rates are low (see below).

\section{Plant abundance, quality and reindeer utilisation}

During the subsequent four summers (1998-2001) after faecal addition, the density of grasses in each plot was established by recording the number of live green shoots in 15 quadrats of $10 \times 10 \mathrm{~cm}$ per plot, which were selected by throwing over the shoulder. Also the number of grazed shoots was recorded to determine average reindeer grazing pressure for each plot. Average shoot mass was determined by clipping off 25 randomly selected grass shoots per plot, which were dried and weighed. Live mass of grasses per plot $\left(\mathrm{g} \mathrm{dw} \mathrm{m}^{-2}\right)$ was obtained by multiplying grass density with shoot mass. Depth of the moss layer was recorded in each plot at 10 predetermined positions by cutting out a turf, and placing a ruler along one of the excavated sides. Tissue $\mathrm{N}$ and $\mathrm{P}$ concentrations were determined in live leaf tips of grasses collected from each plot in August 2001. As the amounts of tissue collected were generally low, material was pooled and 9 pairs of samples were analysed using a continuous flow colorimetric autoanalyser (Segmented flow auto-analyser), following wet acid digestion (Allen 1989).

\section{Soil $\mathrm{N}$ availability and microbial $\mathrm{C}$ and $\mathrm{N}$}

Potential net $\mathrm{N}$ mineralisation was measured as the release of mineral $\mathrm{N}\left(\mathrm{NH}_{4}^{+}-\mathrm{N}\right.$ and $\left.\mathrm{NO}_{3}^{-}-\mathrm{N}\right)$ after incubation of soil samples in the laboratory $(10 \mathrm{~g})$ for $14 \mathrm{~d}$ at $25^{\circ} \mathrm{C}$ (Ross 1990). After incubation, soil samples were extracted with $25 \mathrm{ml} 1 \mathrm{M} \mathrm{KCl}$ for $30 \mathrm{~min}$ on an orbital shaker. The resulting suspension was filtered through Whatman no. 1 paper. The concentration of $\mathrm{NH}_{4}^{+}-\mathrm{N}$ and $\mathrm{NO}_{3}^{-}-\mathrm{N}$ in the extracts was determined by autoanalyser procedures (Ross 1992). Microbial biomass $\mathrm{C}$ and $\mathrm{N}$ were determined in early August 2001 using the fumigation-extraction technique. Soil samples $(5 \mathrm{~g}$ fresh weight) were fumigated with $\mathrm{CHCl}_{3}$ for $24 \mathrm{~h}$ at $25^{\circ} \mathrm{C}$. After removal of the $\mathrm{CHCl}_{3}$, soluble $\mathrm{C}$ was extracted from fumigated and unfumigated samples with $0.5 \mathrm{M}$ $\mathrm{K}_{2} \mathrm{SO}_{4}$ for $30 \mathrm{~min}$ on an end-over-end shaker (soil:solution 1:4 w/v). Total organic $\mathrm{C}$ in filtered extracts was determined using a Shimadzu organic carbon analyser. Microbial C flush (difference between extractable $\mathrm{C}$ from fumigated and unfumigated samples) was converted to microbial biomass $\mathrm{C}$ using a $\mathrm{k}_{\mathrm{EC}}$ factor of 0.35 . Extractable $\mathrm{N}$ in the above extracts was determined by oxidation with $\mathrm{K}_{2} \mathrm{~S}_{2} \mathrm{O}_{8}$, using the methodology of Ross (1992), and measurement of the resultant $\mathrm{NO}_{3}^{-}-\mathrm{N}$ and $\mathrm{NH}_{4}^{+}-\mathrm{N}$ by autoanalyser procedures. The microbial $\mathrm{N}$ flush was converted to microbial biomass $\mathrm{N}$ using a $\mathrm{K}_{\mathrm{EN}}$ factor of 0.54 (Brookes et al. 1985). Basal respiration was measured under laboratory conditions. One $\mathrm{g}$ of moist soil was placed in a $28 \mathrm{ml} \mathrm{McCartney} \mathrm{bottle} \mathrm{at} 25^{\circ} \mathrm{C}$. After 30 min equilibration, the bottle was sealed with a sub-seal and incubated for $24 \mathrm{~h}$. One $\mathrm{ml}$ headspace gas was then removed and $\mathrm{CO}_{2}$ concentration was measured against a $1 \%$ standard gas on an Infra red gas analyser (Analytical Development) and expressed as $\mu \mathrm{l} \mathrm{CO}_{2} \mathrm{~g}^{-1}$ dry soil $\mathrm{h}^{-1}$. Soil moisture content (\% of dry soil) was determined by drying $1 \mathrm{~g}$ of fresh soil for $24 \mathrm{~h}$ at $105^{\circ} \mathrm{C}$.

\section{Decay rate of faecal pats}

Mass loss of faecal pats was determined in an additional experiment that was set up close to the locations where the fouling experiment was conducted. Freshly collected reindeer faeces in the first week of July 2000 were homogenised and used to construct faecal pats of $50 \mathrm{~g}$ wet weight (representing $13.2 \mathrm{~g} \mathrm{dw}$ ). Size, shape and 
consistency of these pats closely resembled natural reindeer summer pats. Four pats were placed out on the tundra vegetation at 45 locations positioned along a $80 \times 600 \mathrm{~m}$ grid cross-cutting a wide range of plant communities. Four locations could not be used due to prolonged snow cover. Two pats were recovered a year later (early August 2001) and, where obtainable, one further pat was sampled three years later (August 2003). All material was weighed after removing mosses from the faeces where present and dried until stable weight at $70^{\circ} \mathrm{C}$ from which $\%$ mass loss of faecal pats was calculated. Faecal mass loss was related to soil moisture content at each location, a measure recorded with a soil insertion capacitance probe (see Van der Wal et al. 2000a for more detail) at weekly intervals throughout the summers of 1999 and 2000, from which an average soil moisture for each position was derived.

\section{Statistical analysis}

Data from the fouling experiment were analysed using generalised linear mixed models with "experimental block" as the random effect. The models were fitted by the method of residual maximum likelihood (REML) in SAS for Windows v.8. Denominator degrees of freedom were estimated using Satterthwaite's approximation (Littell et al. 1996). Data were log-transformed where appropriate, and the residual variances were either modelled as constant (using PROC MIXED) or proportional to the mean (using PROC GLIMMIX with a Poisson error distribution, a free scale parameter and a log-link function) depending on the pattern in the residuals. Autocorrelation between years within plots were modelled as a first-order autoregressive (AR 1) process in the analysis of grass productivity (number of shoots, shoot mass and standing crop) and the reindeer utilisation data. Soil moisture was fitted as a fixed effect in the analysis of the variation in soil microbial $\mathrm{C}$ and grass abundance. The differences between the control and fouled plots in each experimental block were calculated for moss depth, grazing pressure, grass abundance and microbial carbon, and Pearson correlation coefficients between these estimates were calculated. Faecal decomposition data were analysed using generalised linear models with a log-link function and a Poisson error distribution with a free scale parameter.

\section{Results}

The addition of faeces in a single year (1997) had a significant positive effect on the abundance of grasses, which became increasingly evident over the 4-yr research period (Fig. 1). Although the mass of grass shoots, but not shoot density, initially appeared to be suppressed by

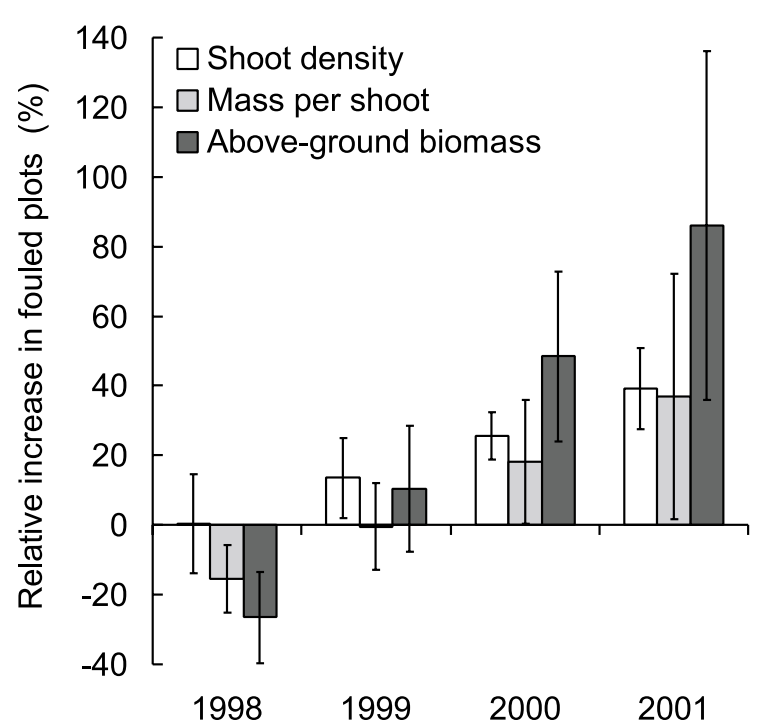

Fig. 1. The development of the response by grasses over four years to faecal addition in 1997, measured as shoot density (no. $\mathrm{m}^{-2}$ ), shoot mass ( $\mathrm{mg}_{\text {shoot }}{ }^{-1}$ ) and total aboveground live mass of grasses $\left(\mathrm{g} \mathrm{m}^{-2}\right)$. Data are expressed as the average $( \pm S E)$ increase in each of these measures in fouled plots relative to the performance of grasses in untreated control plots.

faecal addition, a greater standing crop of grasses resulted from a parallel increase in both shoot density and mass per shoot (Table 1). The apparent decline in plant abundance over the years in plots that did not receive additional faeces may be due to variable summer climatic conditions.

Whereas faecal addition stimulated grass production it tended to negatively influence quality of leaf tips. The concentration of phosphorus in leaf tips four years after faecal addition was significantly lower in fouled plots (dry matter content: $0.032 \pm 0.006 \%$ ) compared to control plots $\left(0.045 \pm 0.005 \% ; \mathrm{F}_{1,8}=5.50, \mathrm{p}<0.05\right)$. Similarly, average nitrogen concentration of grass leaf tips tended to be lower in fouled plots $(0.72 \pm 0.06 \%)$ than in control plots $(0.82 \pm 0.05 \%)$, but differences were not significant $\left(\mathrm{F}_{1,8}=3.23, \mathrm{p}=0.11\right)$.

Reindeer grazing across experimental plots was positively related to the abundance of grasses in anyone year $\left(F_{1,47}=26.74, p<0.0001\right)$ being greatest where grass biomass was high. Yet, this relationship was mainly due to variation at the block level and the increase in grass abundance in fouled plots failed to result in a greater grazing pressure in those plots (fouling: $F_{1,26}=0.27$, $\mathrm{p}>0.6$, fouling $\times$ year: $\mathrm{F}_{3,74}=0.82, \mathrm{p}>0.4$; Fig. 2).

High variability observed in soil parameters limited the detection of strong treatment effects on measures related to microbial biomass, activity and soil nutrient status. However, these measures were consistently greater in fouled plots, and significant treatment effects were established for microbial biomass $\mathrm{C}$ and $\mathrm{N}$ (Table 2). Despite this increase in microbial biomass $\mathrm{C}$ and $\mathrm{N}$, 
Table 1. The performance of grasses during a four-year period in untreated control and experimental plots which received additional faeces in 1997. Measures provided are average $( \pm$ SE) shoot density, mass per shoot and total aboveground live mass of grasses. Not all experimental blocks (N) were successfully relocated in 1998 and 1999. The significance level (p) of F tests on the effect of faecal addition are given for each year separately. Also, summary F statistics on the overall effects of year, fouling and their interaction are provided. Values in bold indicate statistical significance at the $\mathrm{p}<0.05$ level.

\begin{tabular}{|c|c|c|c|c|}
\hline $\begin{array}{l}\text { Shoot density }\left(\text { no } \mathrm{m}^{-2}\right) \\
\text { Year }\end{array}$ & $\mathrm{N}$ & control & fouled & $\mathrm{p}$ \\
\hline $\begin{array}{l}1998 \\
1999 \\
2000 \\
2001\end{array}$ & $\begin{array}{l}13 \\
12 \\
14 \\
14 \\
\text { year: } \\
\text { fouling: } \\
\text { year } \times \text { fouling: }\end{array}$ & $\begin{array}{l}1082(157) \\
975(119) \\
971(182) \\
802(164) \\
F_{3,60}=2.20 \\
F_{1,20}=7.79 \\
F_{3,60}=2.51\end{array}$ & $\begin{array}{l}1086(149) \\
1107(138) \\
1220(191) \\
1117(166) \\
p=0.097 \\
p=\mathbf{0 . 0 1 1} \\
p=0.068\end{array}$ & $\begin{array}{l}0.824 \\
0.248 \\
0.062 \\
\mathbf{0 . 0 0 4}\end{array}$ \\
\hline $\begin{array}{l}\text { Mass per shoot }(\mathrm{mg}) \\
\text { Year }\end{array}$ & $\mathrm{N}$ & control & fouled & $\mathrm{p}$ \\
\hline $\begin{array}{l}1998 \\
1999 \\
2000 \\
2001\end{array}$ & $\begin{array}{l}13 \\
12 \\
14 \\
14 \\
\text { year: } \\
\text { fouling: } \\
\text { year } \times \text { fouling: }\end{array}$ & $\begin{array}{l}14.8(1.2) \\
11.9(0.7) \\
9.3(0.8) \\
10.6(0.7) \\
F_{3,73}=5.42 \\
F_{1,25}=1.80 \\
F_{3,72}=4.18\end{array}$ & $\begin{array}{l}12.5(1.2) \\
11.8(1.0) \\
11.0(0.7) \\
14.5(0.9) \\
p=\mathbf{0 . 0 0 2} \\
p=0.192 \\
p=\mathbf{0 . 0 0 9}\end{array}$ & $\begin{array}{l}0.199 \\
0.965 \\
\mathbf{0 . 0 0 4} \\
\mathbf{0 . 0 0 2}\end{array}$ \\
\hline $\begin{array}{l}\text { Grass live mass }\left(\mathrm{g} \mathrm{m}^{-2}\right) \\
\text { Year }\end{array}$ & $\mathrm{N}$ & control & fouled & $\mathrm{p}$ \\
\hline $\begin{array}{l}1998 \\
1999 \\
2000 \\
2001\end{array}$ & $\begin{array}{l}13 \\
12 \\
14 \\
14 \\
\text { year: } \\
\text { fouling: } \\
\text { year } \times \text { fouling: }\end{array}$ & $\begin{array}{l}16.6(3.0) \\
12.1(2.0) \\
8.3(1.5) \\
8.0(1.5) \\
\mathrm{F}_{3,60}=4.42 \\
\mathrm{~F}_{1,20}=5.55 \\
\mathrm{~F}_{3,61}=10.27\end{array}$ & $\begin{array}{l}12.2(1.6) \\
13.4(2.0) \\
12.3(1.7) \\
15.0(1.9) \\
p=\mathbf{0 . 0 0 7} \\
p=\mathbf{0 . 0 2 9} \\
p=\mathbf{0 . 0 0 1}\end{array}$ & $\begin{array}{l}0.061 \\
0.457 \\
\mathbf{0 . 0 3 6} \\
\mathbf{0 . 0 0 1}\end{array}$ \\
\hline
\end{tabular}

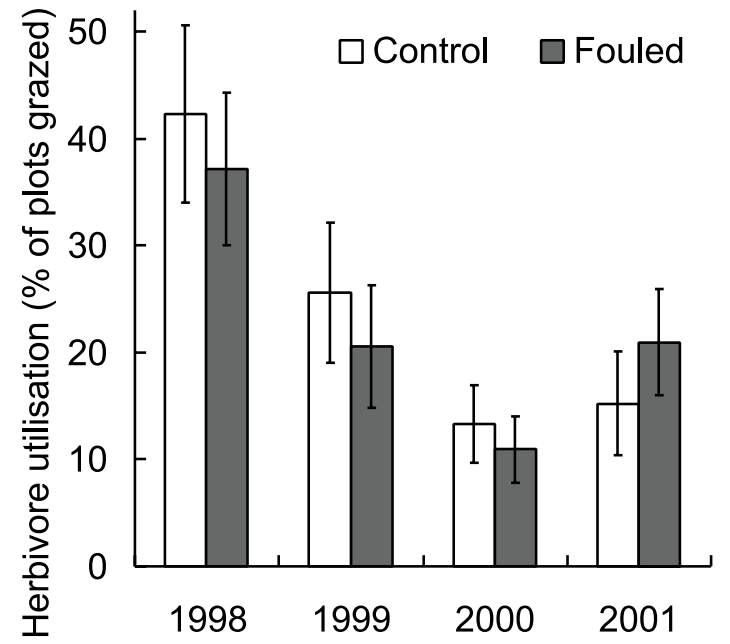

Fig. 2. The utilisation by reindeer over four years of plots which either received additional faecal in 1997 (fouled) or remained untreated (control). Utilisation is calculated as the percentage of subplots with grazed shoots.

there was no significant difference in the metabolic quotient (i.e. $\mathrm{CO}_{2}$ evolution per unit of microbial $\mathrm{C}$ ). The effect of faecal addition on soil microbial biomass $\mathrm{C}$ was found to be dependent on soil moisture levels (Fig. 3a), with no effect of faecal addition when soils were dry, but a strong stimulatory effect on this measure when soils were wet (soil moisture $\times$ fouling interaction: $\left.\mathrm{F}_{1,24}=16.07, \mathrm{p}<0.001\right)$. Interestingly, the reverse appeared to be the case in grasses (Fig. 3b) which reached greatest abundance under dry conditions (soil moisture: $\left.\mathrm{F}_{1,14}=6.07, \mathrm{p}<0.05\right)$ and benefited noticeably from faecal addition (fouling: $\mathrm{F}_{1,13}=7.67, \mathrm{p}<0.02$ ). Although graphical inspection of these data suggest that the greatest impact of fouling occurred under dry conditions, the strong block effect (covariance parameter estimates: block 21.5 vs residual 9.3) prevented the detection of a significant interaction $\left(\mathrm{F}_{1,13}=0.38\right.$, $\mathrm{p}>0.5$ ). Decomposition rates of faecal pats, determined in a grid cross-cutting a wide range of vegetation types, were also found to be significantly related to soil moisture $\left(\mathrm{F}_{1,39}=10.93, \mathrm{p}<0.001\right)$ with greatest reduction in faecal mass over a 13 months time period in wet sites (Fig. 4). Mass loss continued over time and averaged $37.1 \pm 18.2 \%$ after 37 months. By then the relationship between faecal mass loss and soil moisture had broken down $\left(\mathrm{F}_{1,11}=0.78, \mathrm{p}>0.39\right)$.

Whilst biomass of grasses and soil microbes increased due to faecal addition, moss depth was significantly less in fouled plots $(27 \pm 7 \mathrm{~mm})$ compared to control plots 
Table 2. Measurements of soil parameters (crude means \pm standard error across all blocks) from untreated control and experimental plots four years after having received additional faeces. The significance level (p) of $F$ tests on the effect of faecal addition, taking into account the block design, is given for each measurement separately. Values in bold indicate statistical significance at the $\mathrm{p}<0.05$ level.

\begin{tabular}{|c|c|c|c|}
\hline Soil parameter & Control & Fouled & $\mathrm{p}$ \\
\hline Soil $\mathrm{pH}$ & $6.35(0.09)$ & $6.20(0.12)$ & 0.064 \\
\hline Soil moisture ( $\%$ of dry soil) & $44.1(5.3)$ & $48.8(7.1)$ & 0.596 \\
\hline $\mathrm{CO}_{2}$ evolution $\left(\mu \mathrm{l} \mathrm{CO} \mathrm{Cg}^{-1} \mathrm{~h}^{-1}\right)$ & $3.7(0.5)$ & $5.2(0.9)$ & 0.131 \\
\hline Microbial N ( $\mu \mathrm{g} \mathrm{N} \mathrm{g}^{-1}$ dry soil) & $898(148)$ & $1456(237)$ & $\mathbf{0 . 0 3 9}$ \\
\hline Microbial $\mathrm{C}\left(\mu \mathrm{g} \mathrm{C} \mathrm{g}^{-1}\right.$ dry soil) & $970(151)$ & $1790(349)$ & 0.034 \\
\hline Mineralisation rate $\left(\mu \mathrm{g} \mathrm{N} \mathrm{g}^{-1}\right.$ dry soil day $\left.{ }^{-1}\right)$ & $1.9(0.9)$ & $2.5(0.9)$ & 0.606 \\
\hline Soil $\mathrm{NO}_{3}^{-}\left(\mu \mathrm{g} \mathrm{NO}_{2} \mathrm{~g}^{-1}\right.$ dry soil $)$ & $31.0(2.2)$ & $33.3(3.3)$ & 0.597 \\
\hline Soil $\mathrm{NH}_{4}^{+}\left(\mu \mathrm{g} \mathrm{NH} \mathrm{g}^{-1}\right.$ dry soil $)$ & $29.7(2.3)$ & $31.5(2.7)$ & 0.628 \\
\hline Metabolic quotient $\left(\mathrm{ml} \mathrm{CO}_{2}\right.$ per $\left.\mathrm{g} \operatorname{micr} \mathrm{C} \mathrm{h}^{-1}\right)$ & $4.67(0.71)$ & $4.08(0.90)$ & 0.628 \\
\hline
\end{tabular}

(a)
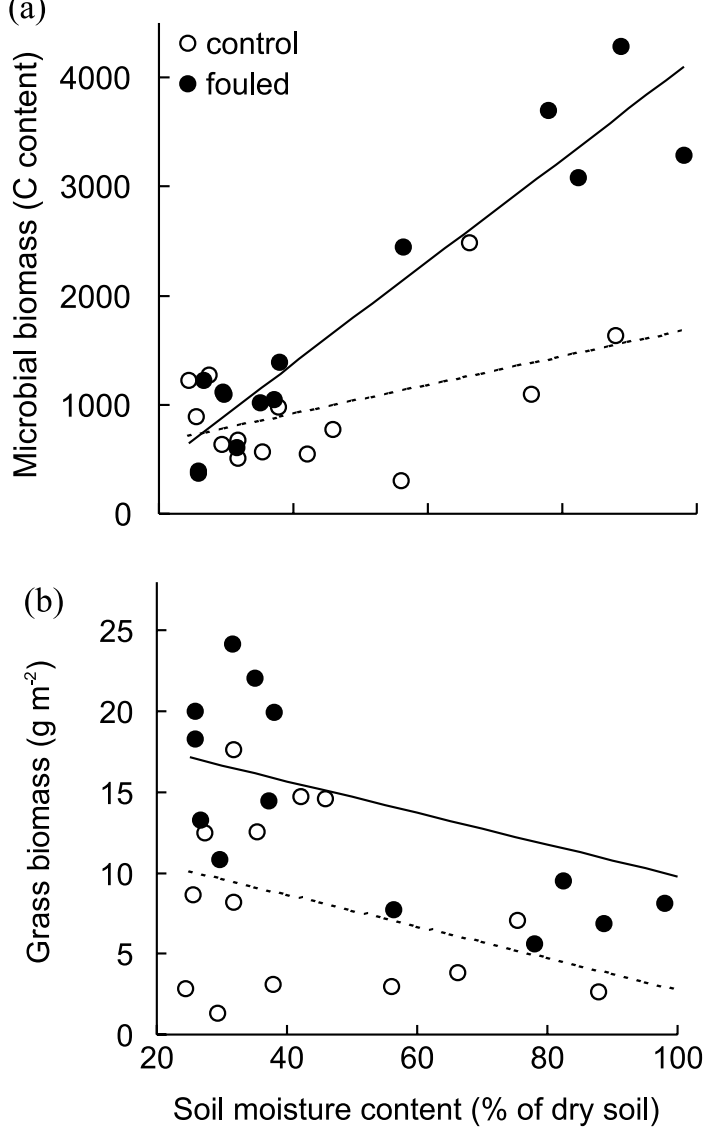

Fig. 3. The relationships of (a) soil microbial carbon content ( $\mu \mathrm{g} \mathrm{C} \mathrm{g}^{-1}$ dry soil) and (b) live aboveground mass of grasses ( $\mathrm{g}$ $\mathrm{m}^{-2}$ ) to soil moisture (\% of dry weight) four years after plots had received additional reindeer faeces (fouled - continuous line) or remained untreated (control - dashed line). In panel (a) both linear models fitted have slopes significantly different from zero (slope fouled: $47.3 \pm 5.0, \mathrm{t}_{24}=9.49, \mathrm{p}<0.0001$; control: $14.1 \pm 6.6, \mathrm{t}_{24}=2.14, \mathrm{p}<0.05$ ). In panel (b) treatments have a common slope $(-0.098 \pm 0.031)$.

$(33 \pm 15 \mathrm{~mm})$ four years after treatment application $\left(\mathrm{F}_{1,13}=18.9, \mathrm{p}<0.001\right)$. Variability in moss depth, measured as coefficient of variation, tended to be greater in fouled plots than in control plots $\left(\mathrm{F}_{1,13}=4.27\right.$, $\mathrm{p}=0.059$ ), suggesting a direct link between the patchy distribution of faeces and the development of the moss mat.

Depth of the moss layer was negatively related to the biomass of grasses across all plots $\left(\mathrm{F}_{1,26}=26.64\right.$, $\mathrm{p}<0.0001$; Fig. 5) with faecal addition resulting in a greater grass cover and concurrent reduction in moss depth. A shallower moss layer in the fouled plots relative to their controls was observed in 12 out of the 14 pairs, whereas grass biomass was greater in all of the fouled plots compared to their associated controls (Fig. 5). Although moss depth was greatest where reindeer grazing pressure was low, grazing appeared not to be instrumental in the reduction of the depth of the moss layer observed in this experiment, as the difference in moss depth between a control and associated fouled plot did not negatively correlate with the difference in grazing pressure experienced by that same pair of plots $(\mathrm{r}=$ $-0.186, \mathrm{n}=14, \mathrm{p}>0.2)$. Similarly, increased grass abundance in fouled plots did not appear to be responsible for the reduction in moss depth, as the difference in moss depth between a control and associated fouled plot did not correlate with the difference in grass abundance $(\mathrm{r}=0.227, \mathrm{n}=14, \mathrm{p}>0.2)$. Yet, the greatest difference in moss depth between control and associated fouled plot was found for those pairs of plots in which fouling resulted in greatest differences in soil moisture $(\mathrm{r}=-0.49, \mathrm{n}=14, \mathrm{p}<0.05)$ and microbial biomass $\mathrm{C}$ relative to control plots $(\mathrm{r}=-0.44, \mathrm{n}=14$, $\mathrm{p}<0.05)$.

\section{Discussion}

Our field experiments demonstrate that by the production of faeces alone, vertebrate herbivores can have a substantial impact on tundra ecosystems. Faecal additions were instrumental in increasing the biomass of grasses and soil microbes, but directly or indirectly reduced the depth of the moss layer. Our findings support the assertion that grazing is an important 


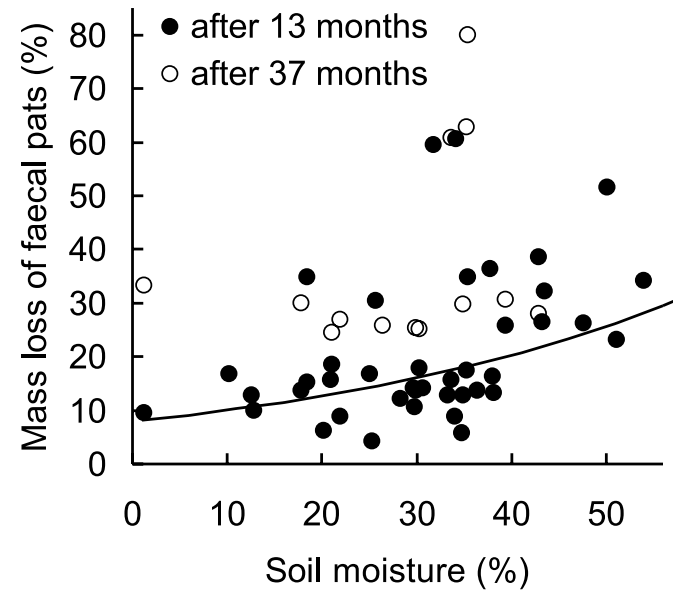

Fig. 4. Dry matter mass loss of fresh faecal reindeer pats over a period of 13 months and 37 months in relation to average volumetric soil moisture.

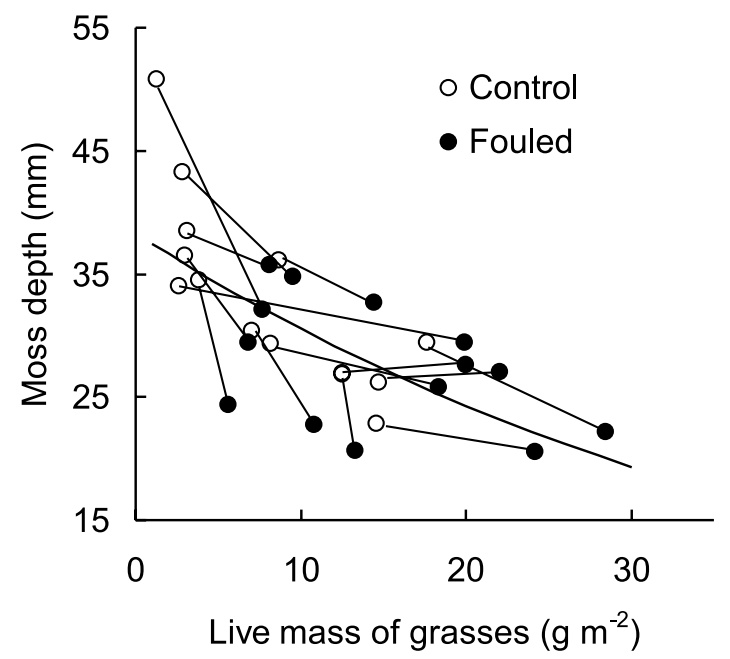

Fig. 5. Relationships between depth of the moss layer and live mass of grasses four years after plots received additional faeces (fouled plots) and their associated untreated controls. Individual pairs of control and fouled plots are connected. The thick black line indicates the overall relationship between moss depth and grass biomass.

determinant of above and belowground components of tundra ecosystems. (Virtanen 2000, Olofsson et al. 2001), and that indirect herbivore impacts, in particular, may be prevalent in the cold and strongly resource-limited arctic environment (Jefferies 1988, Hik et al. 1991, Jefferies et al. 1994, Van der Wal and Brooker 2004).

\section{The stimulatory effect of faeces on grasses and microbes}

The stimulatory effect of faeces on both grasses and microbes does not come as a surprise. Both urine and faeces provide highly decomposable resources that are rich in labile nutrients, and which have been recorded to stimulate soil microbial biomass (Frank and Evans 1997 , Bardgett et al. 1998b, Bardgett and Wardle 2003), and plant $\mathrm{N}$ acquisition and growth (McNaughton et al. 1997, Frank and Groffman 1998) in a wide range of natural and semi-natural ecosystems. Consistent with the enhancement of soil microbial biomass, measures of microbial activity (basal respiration and net $\mathrm{N}$ mineralisation) also tended to increase following faecal addition. Rates of respiration per unit of microbial biomass were not affected by fouling, implying that the specific activity of microbes remained constant across treatments.

Our experimental study provides the first field experimental evidence in an arctic ecosystem that fertilization by mammalian herbivores promotes vascular plant and soil microbial biomass, but in contrast to temperate or tropical systems, demonstrates the relatively slow response of high-latitude systems to herbivores; it took more than three years before any positive effects of faeces on vascular plant growth became apparent. Moreover, our data suggest that the effects of faeces are dependent on soil moisture, stimulating microbial biomass when soils are wet, and increasing grass growth under drier conditions. Our findings are in line with reindeer exclusion studies from the Fennoscandian tundra where reindeer grazing appeared to largely enhance nutrient cycling (Stark et al. 2002). However, deceleration of soil nutrient cycling was observed in continental sites, where herbivory by both reindeer and rodents occurred largely outside the growing season, perhaps preventing nutrient subsidy from animal waste products at the time of highest nutrient demand in plants and microbes (Stark and Grellmann 2002).

The relatively slow response of grasses to faecal addition is in line with the relatively slow decay rate of reindeer faeces. Faecal mass loss was $<20 \%$ in the first annum in dry or moist locations, whereas in wet places an annual decay rate of $30-60 \%$ was observed, with only limited further decay during the subsequent two years. Such decay rates are an order of magnitude lower than generally observed for faeces of large herbivores in lower latitude ecosystems (Aulak and Babinskawerka 1990, Plumptre and Harris 1995, Palmer and Truscott 2002). On the basis of our findings, we expect the release of nutrients from reindeer faeces to be greatest during a short period early in the season, immediately after snow melt, when soil and vegetation conditions are generally wet (Van der Wal unpubl.). Little nutrient release may occur before the next period of snow melt in the following year, particularly in dry locations. Here, faecal pats rapidly dry out over summer and only rewet under conditions of persistent rain, a circumstance that is uncommon to the high Arctic. 
It is likely that once released from the faecal pats, nutrients will not be available to grass roots since they will be intercepted by the mosses which lack functional root systems and take up water and nutrients directly from the surrounding atmosphere. Differences in the response of graminoids to goose grazing among three arctic sites, for instance, have been attributed to the presence of a moss layer. In sites where mosses were largely absent, goose faeces were key to the compensatory growth of graminoids from grazing (Hik and Jefferies 1990), whereas no such response was observed in moss dominated systems (Gauthier et al. 1995, Bakker and Loonen 1998). The efficacy by which mosses absorb nutrients has repeatedly been demonstrated in $\mathrm{N}$ deposition studies where nutrient solutions were sprayed onto the moss layer (Woodin and Lee 1987, Jónsdóttir et al. 1995). In the latter study, nitrogen was immobilised by thick carpets of the moss Racomitrium lanuginosum thereby preventing vascular plants from taking advantage of the additional nutrients supplied. Yet, in shallower layers of the same moss species, surplus amounts of $\mathrm{N}$ had reached the rhizosphere allowing grasses to benefit from the $\mathrm{N}$ additions, despite the recorded increase in $\mathrm{N}$ concentration in the moss (Pearce and Van der Wal 2002, Van der Wal et al. 2003).

Soil microorganisms may also sequester substantial amounts of nutrients coming from faeces, especially when nutrient limited, making them serious competitors to vascular plants (Jonasson et al. 1996, Hart and Firestone 1991, Michelsen et al. 1999, Bardgett et al. 2003). In some ecosystems, the soil microbial $\mathrm{N}$ pool can approach, or even exceed, that of the plant $\mathrm{N}$ pool, indicating considerable potential for competition (Jonasson et al. 1999, Bardgett et al. 2002). Our finding that microbial biomass $\mathrm{N}$ was significantly greater in fouled plots supports this notion that $\mathrm{N}$ released from faeces was sequestered by the microbial biomass, possibly reducing its availability to plants. As shown in ${ }^{15} \mathrm{~N}$ tracer experiments, such microbial sequestration of $\mathrm{N}$ is likely to act as a sizeable and long-term sink for $\mathrm{N}$ (Nadelhoffer et al. 1999), although in some ecosystems immobilisation is immediate but short-term (Kaye and Hart 1997, Zogg et al. 2000, Bardgett et al. 2003). However, in both cases it is likely that following cell death and subsequent turnover, $\mathrm{N}$ will become available for plant uptake, acting as a more stable long-term sink (Seely and Lajtha 1997, Zogg et al. 2000). This immobilisation and slow turnover of microbial $\mathrm{N}$ could explain the slow response of plants to $\mathrm{N}$ addition through faeces in this system.

We have no means to determine the relative importance of these three factors which may all have contributed to the relatively slow response of grasses to faecal addition. Yet, the prolonged period of faecal decay, together with the observed increase in microbial $\mathrm{N}$, may be the most likely candidates. Interestingly, each factor may dominate in a different part of the tundra ecosystem. Faecal addition had its greatest stimulatory effect on soil microbial biomass under wet conditions, where initial faecal decay rates were greatest. In dry sites, the opposite was found, with no microbial response to faecal addition being detected, but a slow decay rate of faecal pats. From this it is enticing to speculate that the intensity of plant-microbe competition may be strongly influenced by soil moisture conditions.

\section{The suppressive effect of faeces on the moss mat}

The negative effect of faeces on the depth of the moss layer could be due to enhanced grazing pressure on patches where grass abundance had increased, as proposed by Van der Wal and Brooker (2004). They predicted that the positive association of grasses and large herbivores in arctic moss-dominated systems results from two simultaneously operating positive feedback loops. First, herbivore grazing and trampling reduces moss layer depth, leading to increased soil temperatures from which grasses profit (see also Van der Wal et al. 2001a, Brooker and Van der Wal 2004). Second, grasses benefit from grazers as a result of additional nutrients from faeces and urine. Our data clearly support this conceptual model as far as the intertwined nature of the two feedback loops are concerned (increased grass growth followed by reduced moss depth). Yet, the mechanism proposed (i.e., increased attraction to patches with greater grass abundance due to faecal nutrient addition) was found not to be responsible for the suppressive effect of faeces on the moss mat in the field experimental plots as grazing pressure was not greatest in the fouled plots.

An alternative explanation for the reduction in moss depth could be that greater grass cover, resulting from faecal addition, reduced the amount of light reaching the mosses growing underneath. Increased competition for light between vascular plants due to faeces has been observed in an Alaska salt marsh (Mulder and Ruess 1998). However, we have no data to support this notion, and further, the low density of grasses in the experimental plots makes it unlikely that grasses would reduce incident irradiation to any ecologically meaningful degree. Although a critically important factor structuring plant communities in temperate regions (Tilman 1988), competition for light in the high Arctic is thought to be a relatively unimportant factor (Arft et al. 1999).

Interestingly, we found that the level of reduction in moss depth in fouled plots (compared to their associated controls) corresponded with the level of increase in microbial biomass due to fouling. It is possible, therefore, that the increase in soil microbial biomass due to fouling may be linked to a reduction in moss depth through increased moss decomposition rates, particu- 
larly in wet sites. However, this is likely a self-enforcing process since changes in moss depth will also change the microclimate of the soil (Bonan 1992, Van der Wal and Brooker 2004), which will in turn act as a strong determinant of microbial activity in these ecosystems. We did not measure decomposition rates of moss in this study, or its relationships to specific microbial activities, but suggest that this should be a priority for future studies to test this idea.

\section{Manipulation of the food resource}

The promotion of grass growth by faeces is widely acknowledged as a key mechanism by which herbivores can manipulate their food supply (Drent and Van der Wal 1999 and references therein). Whereas our data support this notion with respect to productivity measures, reindeer did not demonstrably make use of the enhanced grass growth; grazing pressure in fouled plots was not significantly greater than in the untreated controls. The lower level of grazing on patches enriched with faeces, noticeable in the first three years after placing out additional faeces, has been interpreted as adaptive behaviour to minimise risk of infection with disease (Van der Wal et al. 2000a). However, in the last year of the experiment, a greater interest by reindeer in fouled, rather than untreated control plots, was observed. This suggests that the plots have reached a stage at which the trade-off between nutrient intake and faecal avoidance (Hutchings et al. 1999) is in favour of utilising the greater plant availability. We expect that the reduction in nutrient content due to fouling has been of limited impact to the grazing decisions by Svalbard reindeer, as field experimental manipulations have demonstrated the overriding importance of forage quantity in such a low resource habitat (Van der Wal et al. 2000b).

\section{Herbivore faeces and tundra ecosystem control}

We have demonstrated that increased herbivore impact via faeces allows the development of grass-rich tundra at the expense of the moss layer. Similarly, exclusion of herbivores by fencing results in a significant increase in the extent and depth of the moss layer, as observed in the same study area (Van der Wal and Brooker 2004) and in other arctic tundra ecosystems (Miller et al. 1980, Virtanen 2000, Olofsson et al. 2001, Van der Wal et al. 2001a). As previously discussed, increased decomposition may have been a key factor in the reduction of the moss layer. However, increased grazing pressure resulting from longer-term increase in grass productivity is likely to become an increasingly important determinant of moss depth in subsequent years. The observed inverse relationship between grasses and mosses, which can be interpreted as niche partitioning, may therefore in fact reflect the long history of plant-herbivore interactions in tundra ecosystems.

Acknowledgements - We thank Anna Lena Brathen and Yvonne Halle for helping to set up the fouling plots, Steve Palmer for statistical advice, and Steve Albon, Justin Irvine, Sari Stark and David Wardle for their valuable comments on an earlier version of this paper. Justin Irvine was also instrumental in successfully running the Semmeldalen camp for years on end and provided critical information on faecal decomposition rates. UNIS provided invaluable logistical help. Maddie Thurlow helpfully analysed $\mathrm{N}$ and $\mathrm{P}$ in grass leaves. The Norwegian Research Council (ALV), Centre for Ecology and Hydrology (Integrating Fund) and Natural Environment Research Council (NERC) supported the study financially.

\section{References}

Allen, S. 1989. Chemical analysis of ecological materials. Blackwell.

Arft, A. M. et al. 1999. Response patterns of tundra plant species to experimental warming: a meta-analysis of the International Tundra Experiment. - Ecol. Monogr. 69: $491-511$.

Augustine, D. and McNaughton, S. 1998. Ungulate effects on the functional species composition of plant communities: herbivore selectivity and plant tolerance. - J. Wildl. Manage. 62: 1165-1183.

Aulak, W. and Babinskawerka, J. 1990. Estimation of roe deer density based on the abundance and rate of disappearance of their feces from the forest. - Acta Theriol. 35: 111-120.

Bakker, C. and Loonen, M. J. J. E. 1998. The influence of goose grazing on the growth of Poa arctica: overestimation of overcompensation. - Oikos 82: 459-466.

Bardgett, R. D. and Wardle, D. A. 2003. Herbivore mediated linkages between aboveground and belowground communities. - Ecology 84: 2258-2268.

Bardgett, R. D., Wardle, D. A. and Yeates, G. W. 1998a. Linking above-ground and below-ground interactions: how plant responses to foliar herbivory influence soil organisms. - Soil Biol. Biochem. 30: 1867-1878.

Bardgett, R. D. et al. 1998b. Dynamic interactions between soil fauna and microorganisms in upland grassland soils: a microcosm experiment. - Soil Biol. Biochem. 30: 531-539.

Bardgett, R. D. et al. 2002. Linkages between soil biota, nitrogen availability, and plant nitrogen uptake in a mountain ecosystem in the Scottish Highlands. - Appl. Soil Ecol. 19: $121-134$.

Bardgett, R. D., Streeter, T. and Bol, R. 2003. Soil microbes compete effectively with plants for organic nitrogen inputs to temperate grasslands. - Ecology 84: 1277-1287.

Bonan, G. B. 1992. Soil temperature as an ecological factor in boreal forests. - In: Shugart, H. H., Leemans, R. and Bonan, G. B. (eds), A system analysis of the global boreal forest. Cambridge Univ. Press, pp. 126-143.

Brooker, R. and Van der Wal, R. 2003. Can soil temperature direct the composition of high Arctic plant communities? - J. Veg. Sci. 14: 535-542.

Brookes, P. C. et al. 1985. Chloroform fumigation and the release of soil nitrogen: a rapid direct extraction method to measure microbial biomass nitrogen in soil. - Soil Biol. Biochem. 17: 837-842.

Drent, R. H. and Van der Wal, R. 1999. Cyclic grazing in vertebrates and the manipulation of the food resource. - In: Olff, H., Brown, V. K. and Drent, R. H. (eds), Herbivores: between plants and predators. Blackwell, pp. 271-299.

Forchhammer, M. C. et al. 2002. Long-term responses in arctic ungulate dynamics to changes in climatic and trophic processes. - Pop. Ecol. 44: 113-120. 
Frank, D. and Evans, R. 1997. Effects of native grazers on N cycling in a north-temperate grassland ecosystem: Yellowstone National Park. - Ecology 78: 2238-2249.

Frank, D. and Groffman, P. 1998. Ungulate vs. landscape control of soil $\mathrm{C}$ and $\mathrm{N}$ processes in grasslands of Yellowstone National Park. - Ecology 79: 2229-2241.

Gauthier, G. et al. 1995. Effect of grazing by greater snow geese on the production of graminoids at an arctic site (Bylot Island, NWT, Canada). - J. Ecol. 83: 653-664.

Grime, J. P. et al. 1996. Evidence of a causal connection between anti-herbivore defence and the decomposition rate of leaves. - Oikos 77: 489-494.

Hamilton, E. and Frank, D. 2001. Can plants stimulate soil microbes and their own nutrient supply? Evidence from a grazing tolerant grass. - Ecology 82: 2397-2402.

Hart, S. C. and Firestone, M. 1991. Forest floor mineral soil interactions in the internal nitrogen cycle of an old-grown forest. - Biogeochemistry 12: 103-127.

Hik, D. S. and Jefferies, R. L. 1990. Increases in the net aboveground primary production of a salt- marsh forage grass: a test of the predictions of the herbivore-optimization model. - J. Ecol. 78: 180-195.

Hik, D. S., Sadul, H. and Jefferies, R. L. 1991. Effects of the timing of multiple grazings by geese on net aboveground primary production of swards of Puccinellia phryganoides. - J. Ecol. 79: 715-730.

Hobbs, N. T. 1996. Modification of ecosystems by ungulates. - J. Wildl. Manage. 60: 695-713.

Hutchings, M. et al. 1999. Trade-offs between nutrient intake and faecal avoidance in herbivore foraging decisions: the effect of animal parasitic status, level of feeding motivation and sward nitrogen content. - J. Anim. Ecol. 68: 310-323.

Jano, A., Jefferies, R. L. and Rockwell, R. 1998. The detection of vegetational change by multitemporal analysis of LANDSAT data: the effects of goose foraging. - J. Ecol. 86: 93-99.

Jefferies, R. L. 1988. Pattern and process in arctic coastal vegetation in response to foraging by lesser snow geese. - In: Werger, M. et al. (eds), Plant form and vegetation structure, adaptation, plasticity and relationship to herbivory. SPB Acad. Publ., pp. 281-300.

Jefferies, R. L. and Rockwell, R. F. 2002. Foraging geese, vegetation loss and soil degradation in an Arctic salt marsh. - Appl. Veg. Sci. 5: 7-16.

Jefferies, R. L., Klein, D. R. and Shaver, G. R. 1994. Vertebrate herbivores and northern plant communities: reciprocal influence and responses. - Oikos 71: 193-206.

Jonasson, S. et al. 1996. Microbial biomass, C, N and P in two arctic soils and responses to addition of NPK fertilizer and sugar: implications for plant nutrient uptake. - Oecologia 106: $507-515$.

Jonasson, S. et al. 1999. Responses in microbes and plants to changed temperature, nutrient, and light regimes in the arctic. - Ecology 80: 1828-1843.

Jónsdóttir, I. S., Callaghan, T. V. and Lee, J. A. 1995. Fate of added nitrogen in a moss-sedge Arctic community and effects of increased nitrogen deposition. - Sci. Total Environ. 160/161: 677-685.

Kaye, J. P. and Hart, S. C. 1997. Competition for nitrogen between plants and soil microorganisms. - Trends Ecol. Evol. 12: 139-143.

Littell, R. et al. 1996. SAS systems for mixed models. - SAS.

Louda, S. M., Keeler, K. H. and Holt, R. D. 1990. Herbivore influences on plant competitive interactions. - In: Grace, J. B. and Tilman, D. (eds), Perspectives on plant competition. Academic Press, pp. 413-444.

Manseau, M., Huot, J. and Crête, M. 1996. Effects of summer grazing by caribou on composition and productivity of vegetation: community and landscape level. - J. Ecol. 84: $503-513$.

McNaughton, S., Banyikwa, F. F. and McNaughton, M. M. 1997. Promotion of the cycling of diet-enhancing nutrients by African grazers. - Science 278: 1798-1800.
Michelsen, A. et al. 1999. Differential responses of grass and a dwarf shrub to long-term changes in soil microbial biomass $\mathrm{C}, \mathrm{N}$ and $\mathrm{P}$ following factorial addition of NPK fertiliser, fungicide and labile carbon to a heath. - New Phytol. 143: $523-538$.

Miller, P. et al. 1980. Biophysical processes and primary production. - In: Brown, J. et al. (eds), An Arctic ecosystem: the coastal tundra at Barrow, Alaska. Hutchinson and Ross, Dowden.

Molvar, E. M., Bowyer, R. T. and Van Ballenberghe, V. 1993. Moose herbivory, browse quality, and nutrient cycling in an Alaskan treeline community. - Oecologia 94: 473-479.

Mulder, C. P. H. and Ruess, R. W. 1998. Effects of herbivory on arrowgrass: interactions between geese, neighboring plants, and abiotic factors. - Ecol. Monogr. 68: 275-293.

Nadelhoffer, K. J. et al. 1999. Nitrogen deposition makes a minor contribution to carbon sequestration in temperate forests. - Nature 298: 145-148.

Olff, H. and Ritchie, M. E. 1998. Effects of herbivores on grassland plant diversity. - Trends Ecol. Evol. 13: 261-265.

Olofsson, J. et al. 2001. Effects of summer grazing by reindeer on composition of vegetation, productivity and nitrogen cycling. - Ecography 24: 13-24.

Øritsland, N. A. and Alendal, E. 1986. Svalbardreinen: bestandens störelse og livshistorie. - In: Øritsland, N. A. (ed.), Svalbardreinen og dens livsgrunnlag. Universitetsforlaget, Oslo, pp. 52-60.

Pacala, S. and Crawley, M. 1992. Herbivores and plant diversity. - Am. Nat. 140: 243-260.

Palmer, S. and Truscott, A.-M. 2002. Seasonal habitat use and browsing by deer in Caledonian pinewoods. - For. Ecol. Manage. 5983: 1-18.

Pastor, J. et al. 1988. Moose, microbes and the boreal forest. - Bioscience 38: 770-777.

Pearce, I. S. K. and Van der Wal, R. 2002. Effects of nitrogen deposition on growth and survival of montane Racomitrium lanuginosum heath. - Biol. Conserv. 104: 83-89.

Plumptre, A. and Harris, S. 1995. Estimating biomass of large mammalian herbivores in tropical montane forest: a method of faecal counting that avoids assuming a 'steady state' system. - J. Appl. Ecol. 32: 111-120.

Ross, D. J. 1990. Influence of soil mineral-nitrogen content on soil respiratory activity and measurements of microbial carbon and nitrogen by fumigation-incubation procedures. - Aust. J Soil Res. 28: 311-321.

Ross, D. J. 1992. Influence of sieve mesh size on estimates of microbial carbon and nitrogen by fumigation-extraction procedures in soils under pasture. - Soil Biol. Biochem. 24: $343-350$.

Seely, B. and Lajtha, K. 1997. Application of a $15 \mathrm{~N}$ tracer to simulate and track the fate of atmospherically deposited $\mathrm{N}$ in the coastal forests of the Waquoit Bay Watershed, Cape Cod, Massachusetts. - Oecologia 112: 393-402.

Stark, S. and Grellmann, D. 2002. Soil microbial responses to herivory in an arctic tundra heath at two levels of nutrient availability. - Ecology 83: 2736-2744.

Stark, S., Strommer, R. and Tuomi, J. 2002. Reindeer grazing and soil microbial processes in two suboceanic and two subcontinental tundra heaths. - Oikos 97: 69-78.

Tilman, D. 1988. Plant strategies and the dynamics and structure of plant communities. - Princeton.

Van der Wal, R. et al. 2000a. Faecal avoidance and the risk of infection by nematodes in a natural population of reindeer. - Oecologia 124: 19-25.

Van der Wal, R. and Brooker, R. W. 2004. Mosses mediate grazer impacts on grass abundance in arctic ecosystems. - Funct. Ecol., in press.

Van der Wal, R. et al. 2000b. Trading forage quality for quantity? Plant phenology and patch choice by Svalbard reindeer. - Oecologia 123: 108-115.

Van der Wal, R., Van Lieshout, S. M. J. and Loonen, M. J. E. E. 2001a. Herbivore impact on moss depth, soil temperature and arctic plant growth. - Polar Biol. 24: 29-32. 
Van der Wal, R. et al. 2001b. Differential effects of reindeer on high Arctic lichens. - J. Veg. Sci. 12: 705-710.

Van der Wal, R. et al. 2003. Interplay between nitrogen deposition and grazing causes habitat degradation. - Ecol. Lett. 6: 141-146.

Virtanen, R. 2000. Effects of grazing on above-ground biomass on a mountain snowbed, NW Finland. - Oikos 90: 295300.

Wardle, D. A. 2002. Communities and ecosystems: linking aboveground and belowground components. - Princeton Univ. Press.

Wedin, D. and Tilman, D. 1990. Species effects on nitrogen cycling; a test with perennial grasses. - Oecologia 84: 433 441.
Wegener, C. and Odasz-Albrigtsen, A. 1998. Do Svalbard reindeer regulate standing crop in the absence of predators? A test of the "exploitation ecosystems" model. - Oecologia 116: 202-206.

Woodin, S. J. and Lee, J. 1987. The effects of nitrate, ammonium and temperature on nitrate reductase activity in Sphagnum species. - New Phytol. 105: 103-105.

Zogg, G. et al. 2000. Microbial immobilization and the retention of anthropogenic nitrate in a northern hardwood forest. - Ecology 81: 1858-1866. 